\title{
GluN2B-Containing NMDA Receptors Promote Glutamate Synapse Development in Hippocampal Interneurons
}

\author{
(DWolfgang Kelsch, ${ }^{1 \star}$ Zhijun Li, ${ }^{2 \star}$ Sebastian Wieland, ${ }^{1 \star}$ Oleg Senkov, ${ }^{2,3}$ Anne Herb, ${ }^{2}$ Christina Göngrich, ${ }^{2,4}$ \\ and Hannah Monyer ${ }^{2}$ \\ ${ }^{1}$ Central Institute of Mental Health, Medical Faculty Mannheim, Heidelberg University, 68159 Mannheim, Germany, ${ }^{2}$ Department of Clinical Neurobiology, \\ Medical Faculty of Heidelberg University and German Cancer Research Center (DKFZ), 69120 Heidelberg, Germany, ${ }^{3}$ Molecular Neuroplasticity Group, \\ DZNE, 39120 Magdeburg, Germany, and ${ }^{4}$ Department of Neuroscience, Karolinska Institute, 17177 Stockholm, Sweden
}

In postnatal development, GluN2B-containing NMDARs are critical for the functional maturation of glutamatergic synapses. GluN2Bcontaining NMDARs prevail until the second postnatal week when GluN2A subunits are progressively added, conferring mature properties to NMDARs. In cortical principal neurons, deletion of GluN2B results in an increase in functional AMPAR synapses, suggesting that GluN2B-containing NMDARs set a brake on glutamate synapse maturation. The function of GluN2B in the maturation of glutamatergic inputs to cortical interneurons is not known. To examine the function of GluN2B in interneurons, we generated mutant mice with conditional deletion of GluN2B in interneurons $\left(\mathrm{GluN} 2 \mathrm{~B}^{\Delta \mathrm{GAD} 67}\right)$. In GluN2B ${ }^{\Delta \mathrm{GAD} 67}$ mice interneurons distributed normally in cortical brain regions. After the second postnatal week, GluN2B ${ }^{\Delta \mathrm{GAD} 67}$ mice developed hippocampal seizures and died shortly thereafter. Before the onset of seizures, GluN2B-deficient hippocampal interneurons received fewer glutamatergic synaptic inputs than littermate controls, indicating that GluN2B-containing NMDARs positively regulate the maturation of glutamatergic input synapses in interneurons. These findings suggest that GluN2B-containing NMDARs keep the circuit activity under control by promoting the maturation of excitatory synapses in interneurons.

Key words: GluN2B; hippocampus; interneurons; NMDARs; postnatal development; seizures

\section{Introduction}

The neonatal development of fast excitatory transmission at glutamatergic synapses is tightly regulated. Glutamatergic synapses contain mainly two types of glutamate receptors, AMPARs and NMDARs, which are equipped with unique activation properties (Nakanishi, 1992). In particular, NMDARs were found to serve a critical role in circuit assembly (Forrest et al., 1994; Li et al., 1994; Kutsuwada et al., 1996; Iwasato et al., 2000; Tashiro et al., 2006). NMDARs are composed of the obligatory GluN1 subunit and variable GluN2 subunits. In most forebrain regions, the expression is developmentally regulated. In rodents, GluN2B-containing NMDARs prevail until the second to third postnatal week when the GluN2A subunit is progressively added, conferring mature

\footnotetext{
Received March 24, 2014; revised Aug. 14, 2014; accepted Sept. 29, 2014.

Author contributions: W.K., S.W., Z.L., O.S., C.G., and H.M. designed research; W.K., S.W., Z.L., O.S., A.H., and C.G. performed research; W.K., A.H., and H.M. contributed unpublished reagents/analytic tools; W.K., S.W., Z.L., O.S., A.H., and C.G. analyzed data; W.K., S.W., O.S., C.G., and H.M. wrote the paper.

The work was supported by a Deutsche Forschungsgemeinschaft Emmy-Noether Grant(KE1661/1-1) to W.K. and Schilling Foundation to H.M. We thank Irmgard Preugschat-Gumprecht and Ulla Amtmann for technical help and Dr. Peggy Schneider for initial help with video tracking.

*W.K., Z.L., and S.W. contributed equally to this work.

The authors declare no competing financial interests.

Correspondence should be addressed to Dr. Hannah Monyer, Department of Clinical Neurobiology, Medical Faculty of Heidelberg University and German Cancer Research Center (DFKZ), 69120 Heidelberg, Germany. E-mail: h.monyer@dkfz-heidelberg.de.

Z. Li's present address: Department of Neurology, Tongji Hospital, Huazhong University of Science and Technology, 430030 Hubei, China.

DOI:10.1523/JNEUROSCI.1210-14.2014

Copyright $\odot 2014$ the authors $\quad 0270-6474 / 14 / 3416022-09 \$ 15.00 / 0$
}

properties to NMDARs (Monyer et al., 1994). The deletion of the GluN1 subunit in all or only in pyramidal neurons during embryonic development impairs the barrel cortex formation (Forrest et al., 1994; Li et al., 1994; Iwasato et al., 2000). Similar, defects in the barrel cortex formation were observed for GluN2Bdeficient mice (Kutsuwada et al., 1996). These GluN2B-deficient mice have an impaired suckling reflex and die shortly after birth. It is currently unknown whether selective deletion of GluN2B in inhibitory interneurons (INs) results in related deficits in circuit assembly.

In early postnatal life, GluN2B-containing NMDARs are critical for the functional maturation of glutamatergic synapses. In a series of studies on excitatory pyramidal neurons, developmental deletion of GluN2B resulted in an increase in functional AMPAR synapses as measured by recordings of action potential-independent mEPSCs (Hall et al., 2007; Gray et al., 2011; Wang et al., 2011). It was hence inferred that the normal function of GluN2Bcontaining NMDARs is to set a brake on glutamatergic synapses in postnatal development during a time period when synaptic activity in the hippocampus continuously increases. In a recent study on adult-born INs of the olfactory bulb, single-cell deletion of GluN2B had an opposite effect, namely GluN2B deletion impaired the development of functional glutamatergic synapses (Kelsch et al., 2012), suggesting that under normal conditions GluN2B-containing NMDARs promote synapse maturation. Two scenarios may explain the opposite function of GluN2Bcontaining NMDARs in excitatory neurons in the neonatal hip- 
pocampus versus adult-born inhibitory INs (Platel and Kelsch, 2013). The low or high levels of excitatory synaptic network drive could be responsible for the opposite function of GluN2Bcontaining NMDARs in the maturation of glutamatergic synapses. Alternatively, GluN2B-containing NMDARs have opposite functions in pyramidal neurons and INs in the postnatal hippocampus. We tested these hypotheses taking recourse to mice with GluN2B deletion that is restricted to INs.

\section{Materials and Methods}

Generation of conditional mutant mice and animal housing. GluN2B ${ }^{\Delta \mathrm{GAD} 67}$ mice were generated by breeding heterozygous targeted knock-in GAD67:Cre mice (Tolu et al., 2010) with GluN2B ${ }^{\text {fl/fl }}$ mice (von Engelhardt et al., 2008) in a C57BL/6N background (Charles River). Subsequently, GluN2B $\mathrm{B}^{\mathrm{fl} / \mathrm{wt}} / \mathrm{GAD} 67: \mathrm{Cre}+$ mice were bred with GluN2B ${ }^{\mathrm{fl} / \mathrm{fl}} / \mathrm{GAD} 67: \mathrm{Cre}-$. As previously described in Magno et al. (2011), heterozygous GAD67:Cre + mice were generated by knock-in of Cre recombinase cDNA into the noncoding region of the gadl gene locus. Mice of either sex were used and were kept in a normal $12 \mathrm{~h}$ daylight cycle under the same housing conditions. Animal procedures were approved by the local Animal Welfare Committee.

Initial characterization of mutant mice. Animals were weighed at the same hour of the day. To exclude major defects in motor development, the locomotor activity was video tracked every second day at different ages (P12-P18) over a period of $10 \mathrm{~min}$. Animals were tested in a type 2 mouse cage and analyzed by video-tracking software (ANY-maze, Stoelting). Also, the time was determined how long GluN2B ${ }^{\Delta \mathrm{GAD} 67}$ mice and their littermate controls could hold onto a horizontal wire placed $25 \mathrm{~cm}$ above a soft ground. The footprint analysis was performed as previously described (Carter et al., 1999). For each step parameter, three values were measured from each run, excluding footprints made at the beginning and end of the run where the animal was initiating and finishing movement, respectively. Locomotor activity, clonic movements, and tremor were documented by videotaping of control and GluN2B ${ }^{\Delta \mathrm{GAD} 67}$ mice from the same litter. To test whether GluN2B ${ }^{\Delta \mathrm{GAD} 67}$ mice died from seizures, we injected the antiepileptic drug valproate intraperitoneally $0.1 \mathrm{mg} / \mathrm{g}$ BW (Rostock et al., 1996) twice a day starting at P10 both in control and GluN2B ${ }^{\Delta \mathrm{GAD} 67}$ mice from the same litter. Valproate was dissolved in $0.9 \%$ sodium chloride solution $(100 \mathrm{mg} / \mathrm{ml})$. The weight and survival were monitored daily.

Histology. Mice were given an overdose of isoflurane, followed by transcardial perfusion with $\mathrm{PBS}$ at $37^{\circ} \mathrm{C}$. Subsequently mice were perfused with 3\% PFA and post fixed in 3\% PFA for $12 \mathrm{~h}$ at $4^{\circ} \mathrm{C}$. Fifty micrometer thick coronal slices were cut with a Leica vibratome. Cytochrome oxidase activity was visualized by incubation of flattened tangential vibratome sections $(100 \mu \mathrm{m})$ in $0.05 \%$ cytochrome $c$, and $0.05 \%$ DAB. For immunohistochemistry, sections were incubated with mouse anti-parvalbumin (PV) antibody (1:4000; Swant) at $4^{\circ} \mathrm{C}$ for $24 \mathrm{~h}$. Sections were sequentially incubated with biotinylated secondary antibody and with peroxidase-avidinbiotin complex and visualized with DAB. For immunofluorescent labeling, $50 \mu \mathrm{m}$ sections were incubated in primary antibodies at $4^{\circ} \mathrm{C}$ overnight, and Alexa 488- and/or Alexa 555-conjugated secondary antibodies (1:750, Invitrogen) diluted in blocking solution at room temperature for $2 \mathrm{~h}$. Primary antibodies were mouse or rabbit anti- PV (1:4000; Swant), mouse anti-NeuN (1:1500; Millipore), mouse anti-VGlut1 (1: 1000; Synaptic Systems), rabbit anti-somatostatin (1:1000; Bachem), rabbit anti-Cre (1:500; Novus Biologicals), and rabbit anti-caspase- 3 antibodies (1:1000; Abcam). Blocking solution contained $0.25 \%$ Triton X-100 and $1 \%$ bovine serum albumin. Sections were mounted with Fluoromount (Sigma). Fluorescent and light microscopy was performed with a Zeiss Axio Examiner microscope. Colocalization of caspase-3 and Cre with parvalbumin or somatostatin was analyzed with a Zeiss LSM700 laser scanning microscope. Single confocal planes of VGlut $1^{+}$puncta on $\mathrm{PV}^{+}$dendrites in stratum oriens and $\mathrm{PV}^{+}$terminals at $\mathrm{NeuN}^{+}$somata in CA1 were acquired with a $63 \times$ oil objective at a zoom factor of 3 . Analysis was performed with ImageJ. The soma was imaged at its largest diameter and the density of $\mathrm{PV}^{+}$terminals was determined by measuring the puncta per micrometer cell surface in a single confocal plane.
GAD67 mRNA detection. Fifty micrometer tissue sections were prepared as described for immunohistochemistry. pBS plasmid containing GAD67 cDNA (Erlander et al., 1991) was linearized with EcoRI and the probe was generated by in vitro transcription using DIG-UTP nucleotide mix and T3/T7 polymerase. Hybridization was performed at $55^{\circ} \mathrm{C}$, followed by posthybridization washes and detection using NBT/BCIP (Thermo Fisher) in conjunction with anti-DIG-AP antibody (1:750; Roche) as previously described (Catania et al., 1995).

In vivo physiology and pharmacology. At age P14-P15, GluN2B ${ }^{\Delta \mathrm{GAD} 67}$ and control pups were taken from the mother and under a short (30 min) isoflurane (1-3\%) anesthesia implanted stereotaxically with three electrodes targeting the $\mathrm{CA} 1$ area of the dorsal right hippocampus (posterior: $1.5 \mathrm{~mm}$; lateral: $1.5 \mathrm{~mm}$; ventral: $1.5-1.7 \mathrm{~mm}$ relative to bregma). Electrodes were made from three Teflon-coated, $140 \mu \mathrm{m}$ tungsten wires bound together and separated with their tips in dorsoventral projection by an increment of $\sim 200-300 \mu \mathrm{m}$. Electrodes were connected to the Neuralynx Electrode-Interface Boards (EIB-32-Narrow) by gold pins. EIBs were cut $2 / 3$ of their length to minimize their weight and size. A ground electrode was placed subdural above the olfactory bulbs. Electrodes and EIBs were fixed on the skull and then secured with dental cement. About $1 \mathrm{~h}$ after recovery from anesthesia, mice underwent electrophysiological recordings. Electrophysiological signals were fed to a small Neuralynx pre-amplifier (gain $\times 1$ ) attached directly to the mouse electrode headstage. To minimize the carrying weight, the recording tether was controlled by a custom-made counterbalance. LFPs were recorded with a Neuralynx acquisition system with $\times 500$ amplification gain, $3030 \mathrm{~Hz}$ sampling rate, and wide-band filter. Recordings were performed in a small plastic box $(20 \times 20 \times 10 \mathrm{~cm})$ covered with grounded aluminum foil in a dimly illuminated room. Recordings in each mouse lasted for $1 \mathrm{~h}$, and subsequently the animal was injected with valproate $(100 \mathrm{mg} / \mathrm{ml}, 0.1 \mathrm{mg} / \mathrm{g} \mathrm{BW}$, i.p.) and recordings were continued for another hour. Analysis of electrophysiological data was performed with NeuroExplorer 4.1 (Nex Technologies) and MATLAB 7.8 (The MathWorks). Power spectral density of hippocampal LFPs was computed in the electrophysiological data analysis software NeuroExplorer (Nex Technologies). Briefly, a fast Fourier transformation of raw power spectrum was performed for $0-40 \mathrm{~Hz}$ frequency band using $1 \mathrm{~h}$ continuous intrahippocampal EEG recording before and after drug injection. Values of peaks in power (LFP power) were averaged across recorded mice and depicted as mean \pm SEM. For spectrograms color-coded power was estimated for every frequency $(0-40 \mathrm{~Hz})$ and plotted over the time of recording.

In vitro recordings. Animals were given an overdose of isoflurane. Brains were incubated in cold recording solution containing the following (in mM): $125 \mathrm{NaCl}, 2.5 \mathrm{KCl}, 1.25 \mathrm{NaH}_{2} \mathrm{PO}_{4}, 26 \mathrm{NaHCO}_{3}, 1 \mathrm{MgCl}_{2}, 2$ $\mathrm{CaCl}_{2}$, and 20 glucose (312 mOsm, pH 7.3, bubbled with $95 \% \mathrm{O}_{2}$ and $5 \%$ $\mathrm{CO}_{2}$ ) and cut into $250 \mu \mathrm{m}$ coronal slices with a Mikrom vibratome. For recovery, slices were incubated at $32^{\circ} \mathrm{C}$ for $30 \mathrm{~min}$ in recording solution. Fluorescence-guided, whole-cell patch-clamp recordings were performed with an EPC-10 amplifier (HEKA). For recordings involving evoked PSCs, the pipette solution contained the following (in mM): 105 Cs-gluconate, $25 \mathrm{CsCl}, 10$ HEPES, $4 \mathrm{Mg}$-ATP, $0.3 \mathrm{GTP}, 10$ Trisphosphocreatine, and 2.5 QX-314-chloride, $\mathrm{pH}$ 7.3, 292 mOsm adjusted with glucose. All other recordings were performed with a pipette solution containing the following (in mM): $120 \mathrm{~K}$-gluconate, $10 \mathrm{HEPES}, 15 \mathrm{KCl}, 4$ Mg-ATP, 7 phosphocreatine, 4 ATP-Mg, 0.3 GTP, and 0.1 EGTA, pH 7.3, $292 \mathrm{mOsmol}$ adjusted with glucose. Pipette resistance ranged from 4 to 7 $\mathrm{M} \Omega$, and cells were only accepted if pipette access resistance was $<25$ $M \Omega$. The junction potential was not corrected throughout the study. Data were acquired with Patchmaster software (HEKA) and analyzed with Igor Pro (WaveMetrics) software. All drugs were purchased from Tocris Bioscience. The resting membrane potential was determined shortly after establishing the whole-cell configuration. Membrane capacitance and resistance were determined by application of a hyperpolarizing pulse. Spontaneous EPSCs (sEPSCs) were recorded at $32^{\circ} \mathrm{C}$. sEPSCs were recorded at $V_{\mathrm{h}}=-70 \mathrm{mV}$ in the presence of gabazine $(10 \mu \mathrm{M})$ and blocked by $10 \mu \mathrm{M}$ CNQX at the end of the recording (data not shown). Recordings of mEPSCs were performed at the same $V_{\mathrm{h}}$ and in the pres- 
ence of $10 \mu \mathrm{M}$ gabazine and $1 \mu \mathrm{M}$ TTX. Ten minutes of continuous recordings were analyzed.

To record evoked PSCs, a unipolar glass stimulation electrode was positioned 30-50 $\mu \mathrm{m}$ from the soma in the stratum oriens. The stimulation intensity and position of the electrode were kept constant $(20-50 \mu \mathrm{A})$ for the duration of the recording. For the E/I (eEPSC/ eIPSC) ratio, eEPSCs were recorded at $V_{\mathrm{h}}=$ $-55 \mathrm{mV}$ and eIPSCs at $V_{\mathrm{h}}=0 \mathrm{mV}$ with pipette solution containing elevated $[\mathrm{Cl}]$. To determine NMDAR/AMPAR-mediated current ratio, EPSCs were first evoked in control solution at $V_{\mathrm{h}}=-70 \mathrm{mV}$ in presence of gabazine $(10 \mu \mathrm{M})$. AMPAR-mediated eEPSCs were blocked subsequently by $10 \mu \mathrm{M}$ CNQX. Finally $V_{\mathrm{h}}$ was changed to $+40 \mathrm{mV}$ and NMDARmediated EPSC were recorded. The remaining evoked currents at $V_{\mathrm{h}}=+40 \mathrm{mV}$ were blocked by $50 \mu \mathrm{M}$ D-AP5.

Biocytin filling of neurons and reconstruction. Brain slices were prepared as described for electrophysiology. Neurons were recorded with 2 $\mu \mathrm{g} / \mathrm{ml}$ biocytin in the pipette for 10-30 min. After the pipette was withdrawn, slices were kept in the recording chamber for an additional $10 \mathrm{~min}$ and subsequently immersion fixed in $4 \%$ PFA at $4^{\circ} \mathrm{C}$ for $8-16 \mathrm{~h}$. Biocytin-filled cells were incubated with peroxidase-avidin-biotin complex (Vector Laboratories) and visualized with DAB-nickel sulfate (Sigma). Subsequently, slices were mounted with Mowiol onto slides. The reconstruction of biocytin-filled neuron was performed with a Neurolucida reconstruction system with a $100 \times$ oil-immersion objective.

Statistical analysis. Except when otherwise indicated, data are reported as mean \pm SEM and analyzed with the two-tailed Student's $t$ test. ANOVA with Tukey's post-test was used for multiple comparisons.

\section{Results}

\section{Characterization of mice deficient for GluN2B in interneurons \\ (GluN2B $^{\Delta \text { GAD67}}$ )}

To examine the function of GluN2Bcontaining NMDARs during postnatal development of INs, we generated conditional mutant mice by crossing mice expressing Cre under the control of the endogenous GAD67-promoter (GAD67: Cre) with mice carrying conditional knock-out alleles for GluN2B (GluN2B ${ }^{\mathrm{f} /}$ f). GluN2B fl/wt $^{\mathrm{fl}}$ GAD67:Cre+ mice bred and survived similarly to GAD:Cre - mice from the same litters. Fewer than expected GluN2B ${ }^{\mathrm{fl} / \mathrm{fl}} / \mathrm{GAD} 67$ : $\mathrm{Cre}+$ mice were born when both parents carried a floxed GluN2B allele $\left(6.2 \%\right.$ of expected $12.5 \%$ GluN2B ${ }^{\mathrm{fl} / \mathrm{fl}} / \mathrm{GAD} 67$ :Cre + mice in 61 litters) or when one parent carried a floxed GluN2B allele and the other one two floxed alleles (9.9\% of expected: $25 \%$ GluN2B ${ }^{\mathrm{fl} / \mathrm{fl}} / \mathrm{GAD} 67:$ Cre + mice in 97 litters).

GluN2B ${ }^{\text {fl/fl } / G A D 67: C r e+~(h e r e a f t e r ~ c a l l e d ~ G l u N 2 B ~}{ }^{\Delta \text { GAD67 }}$ ) were compared with either GluN2B ${ }^{\mathrm{fl} / \mathrm{fl}} / \mathrm{GAD} 67: \mathrm{Cre}-$ or GluN2B ${ }^{\text {fl/wt } / G A D 67: C r e ~-~ m i c e ~(r e f e r r e d ~ t o ~ a s ~ w t ~ c o n t r o l ~ m i c e) ~}$ of the same litter. Shortly after birth, GluN2B ${ }^{\Delta \mathrm{GAD} 67}$ mice had

A1
PO

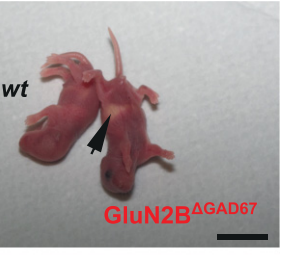

A2

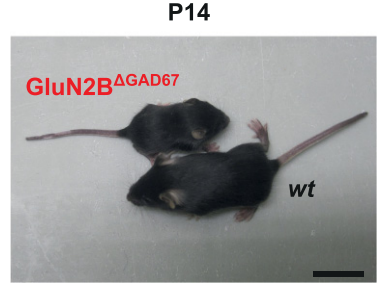

D
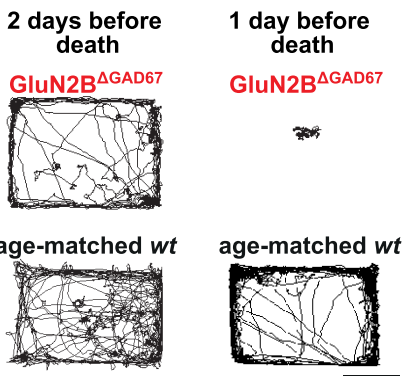

$\mathbf{E}$

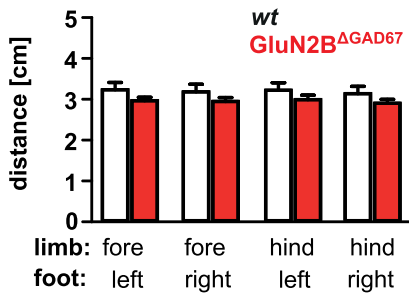

age-matched wt
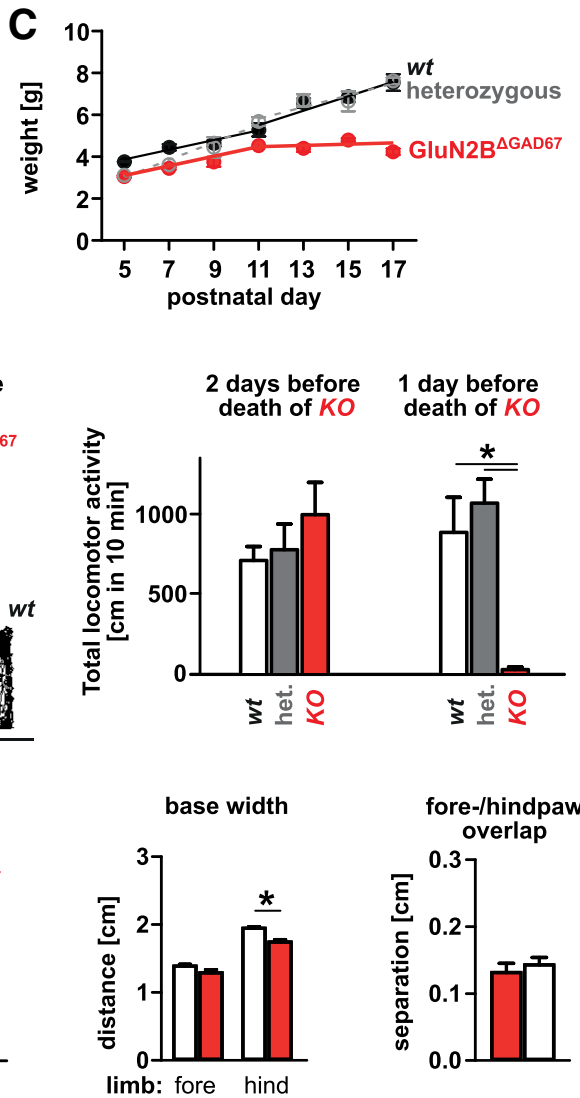

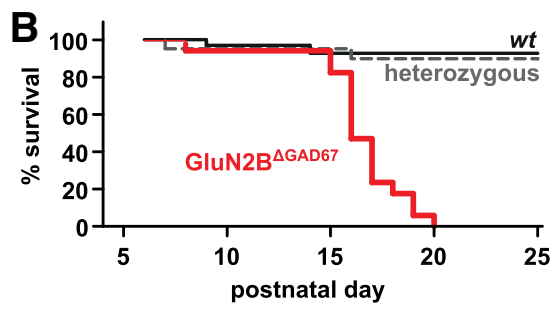

Figure 1. Characterization of GluN2B ${ }^{\triangle \mathrm{GAD} 67}$ mice. $A 1, \mathrm{GluN}_{2} \mathrm{~B}^{\triangle \mathrm{GAD} 67}$ and littermate wt mice had milk in the stomach at $\mathrm{PO}$ Scale bar, $1 \mathrm{~cm}$. $\boldsymbol{A 2}$, GluN2B ${ }^{\triangle \mathrm{GAD67}}$ mice were smaller than their littermates at $\mathrm{P} 14$. Scale bar, $1.5 \mathrm{~cm}$. $\boldsymbol{B}$, Survival curve of

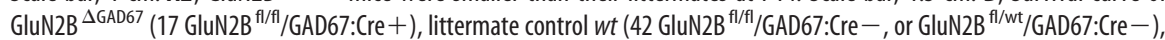
and heterozygous mutant mice (21 GluN2B f//wt/GAD67:Cre+). C, Body weight curves (mean \pm SEM) for GluN2B ${ }^{\triangle 6 A D 67}$, littermate $w t$, and heterozygous mutant mice shown in $\boldsymbol{B}(n=17,42$, and 21 mice, respectively). $\boldsymbol{D}$, Left, Exploratory behavior over a period of 10 min of a GluN2B ${ }^{\triangle G A D 67}$ mouse (top) $2 \mathrm{~d}$ before and $1 \mathrm{~d}$ before its death. GluN2B ${ }^{\triangle G A D 67}$ mice were compared with an age-matched littermate wt mouse (bottom). Scale bar, $10 \mathrm{~cm}$. Right, Total locomotor activity (mean \pm SEM) expressed as the total track length traveled in centimeters during the recorded period ( $10 \mathrm{~min}$ ) in GluN2B ${ }^{\triangle \mathrm{GAD} 67}$ mice $2 \mathrm{~d}$ before (bottom) and $1 \mathrm{~d}$ before their death and in age-matched littermate heterozygous and wt mice (one-way ANOVA: $n . s$. and $p<0.001$, respectively, Tukey's post-test: $p<0.05$ indicated by asterisk; $n=6$ mice per genotype). $\boldsymbol{E}$, For the footprint analysis, stride length, base width, and forepaw/hindpaw overlap (mean \pm SEM) were determined at P10-P12 for GluN2B ${ }^{\triangle G A D 67}$ and littermate wt mice $(n=5$ per genotype, $p<0.05$ indicated by asterisk, $t$ test).

milk in the stomach (Fig. 1A), indicating no overt defect in suckling as previously observed for mice with global deletion of GluN2B (Kutsuwada et al., 1996). There was no significant difference in the survival of GluN2B ${ }^{\Delta \mathrm{GAD} 67}$ mice compared with control littermates until P14 (Fig. 1B). However GluN2B ${ }^{\Delta \mathrm{GAD} 67}$ mice died between P15 and P20. Until P12, GluN2B ${ }^{\Delta \mathrm{GAD} 67}$ mice gained weight comparable to control littermates with a slightly lower, but nonsignificant starting weight (n.s., ANOVA at P5P11, Fig. $1 A 2, C)$. GluN2B ${ }^{\Delta \mathrm{GAD} 67}$ mice initially displayed similar locomotor activity compared with controls, but GluN2B ${ }^{\Delta \mathrm{GAD} 67}$ mice became immobile on the same day or $1 \mathrm{~d}$ before their demise 
A wt

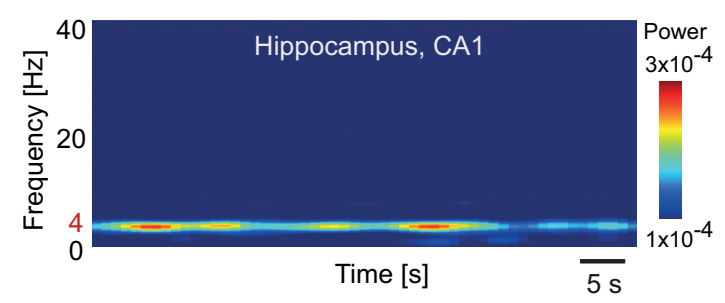

B GluN2B ${ }^{\triangle G A D G 7}$

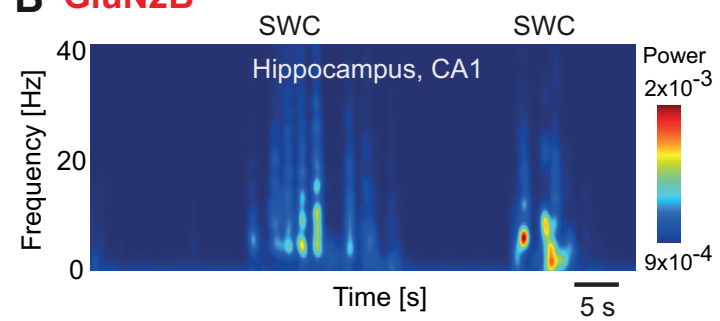

C wt

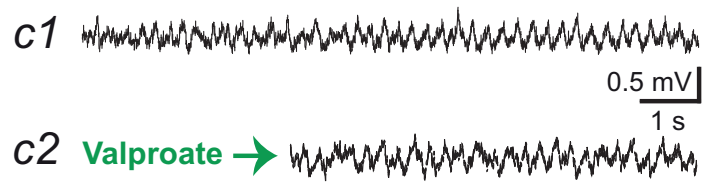

D GluN2B ${ }^{\triangle G A D G 7}$
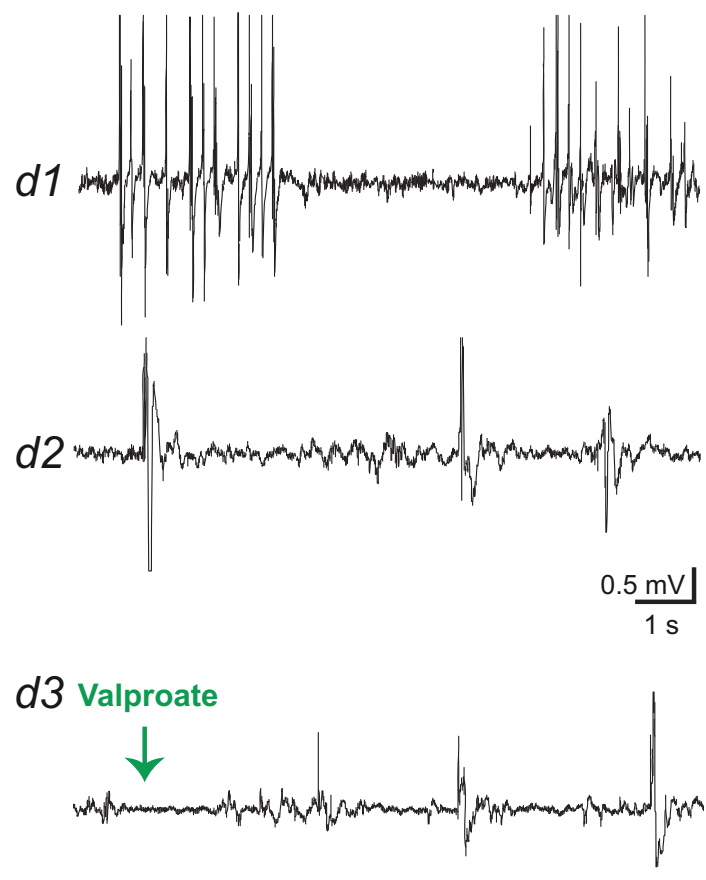

Figure 2. Epileptiform activity in GluN2B ${ }^{\Delta \mathrm{GAD} 67}$ mice and normal hippocampal activity in littermate wt mice recorded in vivo. Spectrograms were derived from recordings in a wt (A) and a littermate GluN2B ${ }^{\triangle G A D 67}$ mouse $(\boldsymbol{B})$ at P15. C, Examples of the hippocampal LFP in a wt mouse (c1) before and (c2) after application of valproate (0.1 mg/g BW) at P15. D, During seizures in a littermate GluN2B ${ }^{\triangle G A D 67}$ mouse, seizure activity in terms of multiple (p)SWCs (d1) and single (p)SWCs (d2) were enriched in the LFP at P15. $\boldsymbol{d} 3$, Single (p)SWCs persisted after intraperitoneal injection of the anti-epileptic drug valproate $(0.1 \mathrm{mg} / \mathrm{g} \mathrm{BW})$.

(Fig. 1D) with little response to external stimuli and showed occasional signs of body tremor (at P15: in 9/10 GluN2B ${ }^{\Delta \mathrm{GAD} 67}$ for at least a consecutive $20 \mathrm{~s}$ during $30 \mathrm{~min}$ observation). No tremor was observed in 10 control mice during the same observation period. Additionally, 6 of 10 GluN2B ${ }^{\Delta \mathrm{GAD} 67}$ mice showed occasional, brief $(<2 \mathrm{~s})$ clonic movements (at least three clonic movements during a 30 min observation period), but cloni were not observed in control littermates. The overall phenotype of the neonatal mutant mice was immobility. We subsequently analyzed gross motor development of P10-P12 GluN2B ${ }^{\Delta \mathrm{GAD} 67}$ and control mice. The footprint analysis revealed no significant differences at this developmental stage in GluN2B ${ }^{\Delta \text { GAD67 }}$ and control littermate mice, except for the average distance of the hindpaws (Fig. 1E). Similarly, no significant difference was observed in muscle strength between 13 GluN2B ${ }^{\Delta \mathrm{GAD} 67}$ and 13 age-matched control littermates held onto an elevated horizontal wire $(23.0 \pm$ 3.1 and $30.4 \pm 4.7 \mathrm{~s}$, respectively, n.s., $t$ test). Together these results suggest that postnatal development was by and large normal until P12.

\section{Valproate-sensitive seizures in GluN2B ${ }^{\Delta \mathrm{GAD67}}$ mice}

We examined in more detail the phenotype of GluN2B ${ }^{\Delta \text { GAD67 }}$ mice around P15 when most animals died. As the development of immobility, clonic movements, and tremor was suggestive of seizures, we tested whether GluN2B ${ }^{\Delta \mathrm{GAD} 67}$ mice could be rescued by intraperitoneal injection of an antiepileptic drug, valproate $(0.1 \mathrm{mg} / \mathrm{g}$ BW, twice a day) starting at P10. Valproate was given to both GluN2B ${ }^{\Delta \mathrm{GAD} 67}$ mice and control littermates and resulted in the survival of 7 of 8 GluN2B ${ }^{\Delta \mathrm{GAD} 67}$ mice until P22. Under valproate, total locomotor activity was relatively normal at P17 in GluN2B ${ }^{\Delta \mathrm{GAD} 6}$ mice compared with control littermates (track length over $10 \mathrm{~min}$ : $1013 \pm 177$ and $1202 \pm 138$ in six mice, respectively, n.s., $t$ test). Under valproate, clonic movements were not observed in seven GluN2B ${ }^{\Delta \mathrm{GAD} 67}$ mice, and intermittent tremor was only observed in one of seven GluN2B ${ }^{\Delta \mathrm{GAD} 67}$ mice at P17 during 30 min of observation. However, from P20 onward, some GluN2B ${ }^{\Delta \mathrm{GAD} 67}$ mice became less mobile and displayed intermittent clonic movements and falling so that we terminated the experiment at P22. Control littermates receiving the same valproate treatment $(n=8)$ displayed no overt changes in mobility. Based on the observations that survival of GluN2B ${ }^{\Delta \text { GAD67 }}$ mice was prolonged by an antiepileptic drug, we performed extracellular recordings from the hippocampus of six awake GluN2B ${ }^{\Delta \text { GAD67 }}$ mice and six littermate control $w t$ mice at P14P15 to establish with certainty that the abnormal motor behavior resulted from seizure activity. Recordings were obtained after the animals recovered from inhalation anesthesia for implantation of electrodes. GluN2B ${ }^{\Delta \text { GAD67 }}$ mice displayed local field potentials with single and multiple (poly)spike wave complexes [(p)SWC]) that were not detected in littermate $w t$ mice (Fig. 2). These discharges in GluN2B ${ }^{\Delta \text { GAD67 }}$ mice were consistently observed throughout the duration of the recording $(1 \mathrm{~h})$. Acute valproate injection $(0.1 \mathrm{mg} / \mathrm{g} \mathrm{BW})$ had acute effects on the epileptic discharges in GluN2B ${ }^{\Delta G A D 67}$ mice. In five GluN2B ${ }^{\Delta G A D 67}$ mice, seizure activity in terms of the number of multiple (p)SWCs (Fig. $2 d 1$ ) decreased from $96.8 \pm 28.4$ to $25.2 \pm 12.6$ events per hour upon administration of valproate $(p=0.02$, paired $t$ test), while epileptic discharges that are frequently also detected after seizures such as single (p)SWCs (Fig. 2d2,d3) persisted (before valproate: $172.2 \pm 82.5$ and after valproate: $290.2 \pm 129.1$ events per hour; n.s., paired $t$ test) and the LFP power decreased from $0.29 \pm 0.07$ to $0.06 \pm 0.02 \mathrm{mV}^{2} / \mathrm{Hz}(p=0.02$, paired $t$ test). Valproate had little effect on the recorded activity in control mice (Fig. 2). Thus, hippocampal recordings 
confirmed that GluN2B ${ }^{\Delta \mathrm{GAD} 67}$ mice exhibited sustained seizure activity at P14-P15 before their death.

\section{Circuit assembly in}

GluN2B ${ }^{\Delta \text { GAD67 }}$ mice

We subsequently focused on cortical circuit assembly and GluN2B-dependent maturation of glutamatergic synapses and examined brain development before the seizures were detectable behaviorally $(<\mathrm{P} 13)$. We focused on two brain regions, namely the barrel field of the somatosensory cortex and the hippocampus. The formation of barrels in the somatosensory cortex is disrupted in global GluN2B knock-out mice. We therefore wondered whether deletion of GluN2B in most INs would also affect the organization of the barrel field. Interestingly, as revealed by cytochrome oxidase chemistry at P10, the histological organization of the barrel field revealed no detectable difference between GluN2B ${ }^{\Delta \mathrm{GAD} 67}$ mice and control littermates ( $n=5$ mice, respectively; Fig. $3 A, B$ ). Also, the barreloids of the thalamus and the barrelettes of the brainstem displayed a normal organization in GluN2B ${ }^{\Delta \mathrm{GAD} 67}$ mice $(n=5$ mice, respectively; Fig. $3 C$ ), suggesting that GluN2B deletion in INs did not interfere with the anatomical formation of the somatosensory barrel structure. Within individual barrels, the density of parvalbumin-immunoreactive $\left(\mathrm{PV}^{+}\right)$cells was comparable between GluN2B ${ }^{\triangle \mathrm{GAD} 67}$ mice and control littermates at P12 (Fig. 3D,E), indicating that in GluN2B ${ }^{\Delta \mathrm{GAD} 67}$ mice $\mathrm{PV}^{+} \mathrm{INs}$ had reached their final target area and survived normally in the somatosensory cortex.

We subsequently focused on the hippocampal formation. The organization and size of the hippocampus did not reveal gross abnormalities in GluN2B ${ }^{\triangle \mathrm{GAD} 67}$ mice compared with control littermates ( $n=5$ mice, respectively; Fig. $4 A$ ). Also the density and distribution of cells expressing GAD67 mRNA were similar in the CA1-CA3 regions and dentate gyrus of GluN2B ${ }^{\Delta \mathrm{GAD} 67}$ mice and littermate controls at P12 (Fig. $4 B, C$ ). In the hippocampus of GAD67:Cre+ mice, 149 of $153 \mathrm{PV}^{+}$and 97 of 99 somatostatin ${ }^{+}$ neurons expressed Cre both in GluN2B ${ }^{\triangle \mathrm{GAD} 67}$ mice at P12 and agematched GluN2B ${ }^{\mathrm{w} t / \mathrm{wt} / G A D 67: C r e+~ m i c e ~(F i g . ~ 4 D, E) . ~ T h e ~ n u m b e r ~ o f ~}$ $\mathrm{PV}^{+}$cells per section was comparable for GluN2B ${ }^{\triangle \mathrm{GAD} 67}$ and littermate control mice in the CA1 and CA3 region and DG $(29.8 \pm 1.1$ vs $26.8 \pm 1.5,52.0 \pm 5.2$ vs $54.4 \pm 2.0,15.2 \pm 1.6$ vs $17.6 \pm 2.3$; $n=6$ mice, respectively, all n.s., $t$ test). No increased levels of cell death were detected by activated caspase- 3 labeling at P15 in GluN2B ${ }^{\Delta \mathrm{GAD} 67}$ mice compared with control littermates in $\mathrm{PV}^{+}$ cells $(0.38$ vs $0.28 \%, n=1166$ and 1350 cells in four mice, respectively; n.s., $t$ test; Fig. $4 F)$ and somatostatin ${ }^{+}$cells $(0.18$ vs $0.12 \%$, $n=1030$ and 1031 cells in four mice, respectively; n.s., $t$ test; Fig. $4 G$ ). Thus at least for $\mathrm{PV}^{+}$and somatostatin ${ }^{+} \mathrm{INs}$, we found no indication of migration, distribution, or survival deficits in GluN2B ${ }^{\Delta \mathrm{GAD} 67}$ mice by the end of the second postnatal week. In addition, we controlled for the possibility that knock-in of Cre into the gadl locus would result in a decreased density of inhibitory ter-

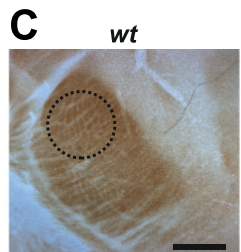

GluN2B ${ }^{\triangle G A D 67}$
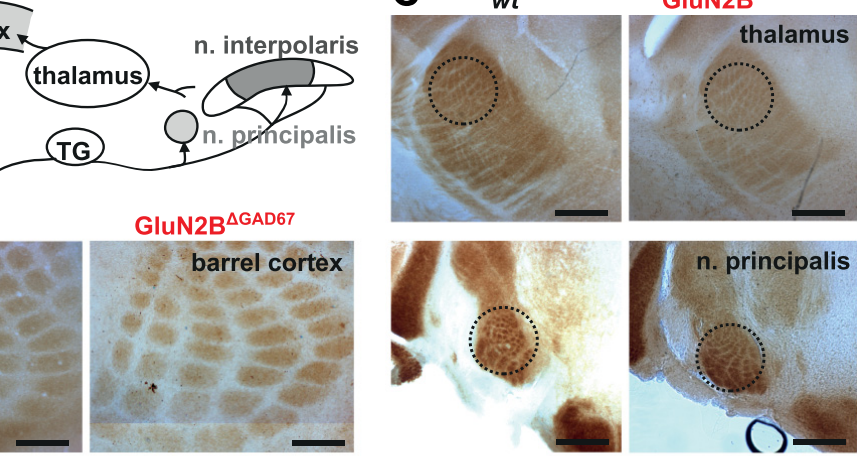

GluN2B $^{\triangle G A D 67}$
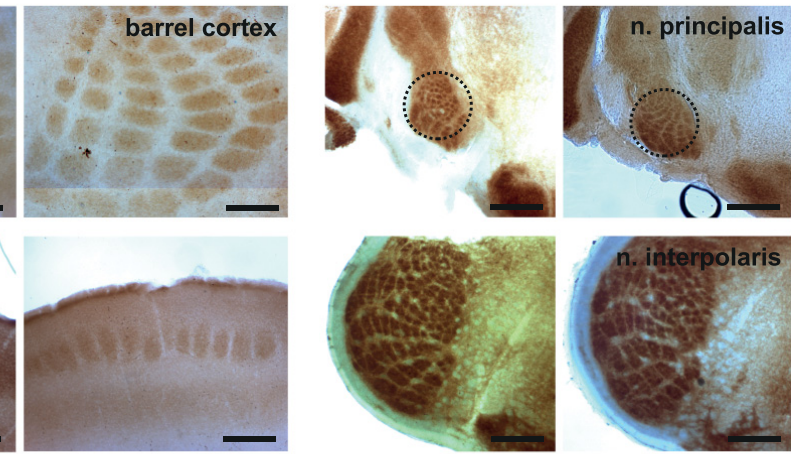

E

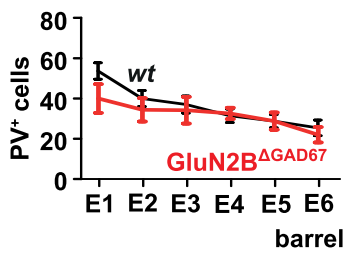

Figure 3. Normal formation of somatosensory barrel structure in GluN2B ${ }^{\triangle \mathrm{GD} 67}$ mice. $A$, The scheme illustrates the trigeminal pathway shown in $\boldsymbol{B}$ and $\boldsymbol{C}$ (TG, trigeminal ganglion). $\boldsymbol{B}$, Cytochrome oxidase staining of the barrel field in the somatosensory cortex of GluN2B ${ }^{\Delta \text { GAD67 }}$ compared with littermate wtmice atP10. Scale bar, $400 \mu \mathrm{m}$. C, Same as $\boldsymbol{B}$ for the barreloids of the thalamus (scale bar, 350 of the barrel cortex of GluN2B ${ }^{\triangle G A D 67}$ and littermate wt mice. Scale bar, $400 \mu \mathrm{m}$. $\boldsymbol{E}$, Number (mean \pm SEM) of PV ${ }^{+}$cells per barrel (from E1 to E6) in GluN2B ${ }^{\triangle \mathrm{GAD} 67}$ and littermate wt mice at P12 ( $n=7$ mice, respectively, n.s., ANOVA).

minals at CA1 pyramidal neurons. We therefore quantified the density of $\mathrm{PV}^{+}$terminals at $\mathrm{NeuN}^{+}$somata in the CA1 pyramidal cell layer at P20. In GAD67:Cre - and GAD67:Cre+ littermates (GluN2B ${ }^{\mathrm{wt} / \mathrm{wt}}$ ), we observed a comparable density of $\mathrm{PV}^{+}$terminals $(6.1 \pm 0.2$ and $5.5 \pm 0.2$ per soma circumference in 40 and 44 $\mathrm{NeuN}^{+}$somata in four mice, respectively; n.s., $t$ test). These observations suggest that although knock-in into the gad l locus affects the level of GAD67 protein expression (Tamamaki et al., 2003; Chattopadhyaya et al., 2007), the genetic manipulation has no significant effect on the number of inhibitory release sites, at least not for $\mathrm{PV}^{+}$ terminals onto CA1 pyramidal neurons at this developmental stage. We cannot rule out the presence of more subtle effects or the possibility that GluN2B deletion affects other IN types.

\section{Maturation of glutamatergic synapses in INs of} GluN2B ${ }^{\Delta \text { GAD67 }}$ mice

We next examined potential consequences of GluN2B deletion in INs on the functional development of glutamatergic synapses. We recorded at P12-P13 from INs that can be readily identified in acute hippocampal slices. We selected INs with the cell body in stratum oriens and confirmed IN identity based on the firing pattern and morphology $(n=10$; Fig. $5 A)$. We examined evoked synaptic glutamatergic currents in the presence of gabazine (10 $\mu \mathrm{M})$ with sequential block of AMPA- and NMDAR-mediated EPSCs (CNQX, $10 \mu \mathrm{M}$, and D-AP5, $50 \mu \mathrm{M}$, respectively; Fig. $5 B$ ). In $w t$ mice, all recorded INs exhibited NMDAR-mediated EPSCs. The ratio of NMDAR/AMPAR-mediated eEPSCs was reduced in GluN2B ${ }^{\Delta \mathrm{GAD} 67}$ mice compared with age-matched $w t$ littermates 
A

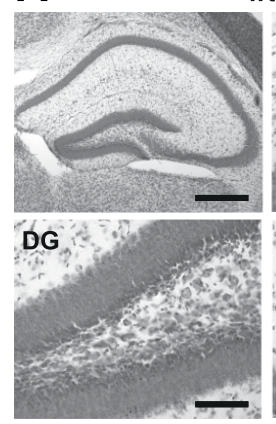

wt

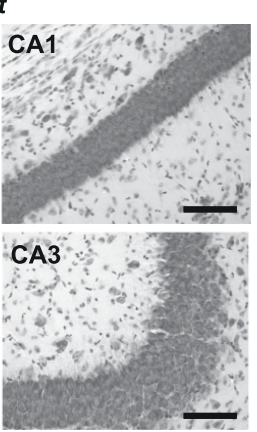

B
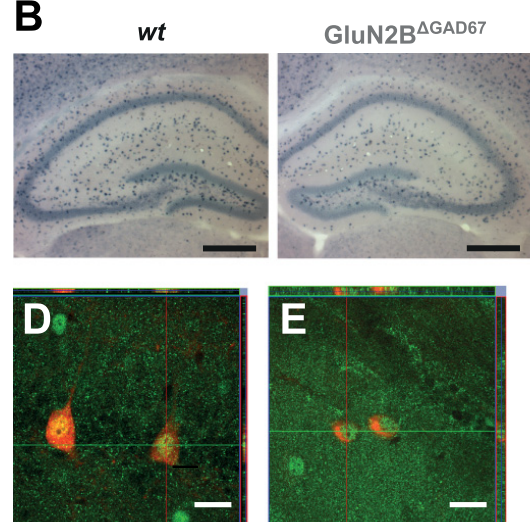

Cre

PV

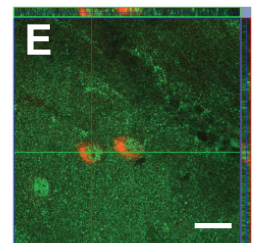

Cre

Somatostatin
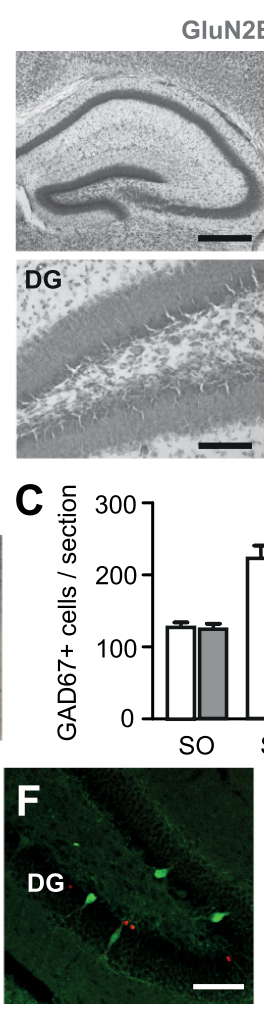

PV

Caspase-3
GluN2B ${ }^{\triangle G A D 67}$

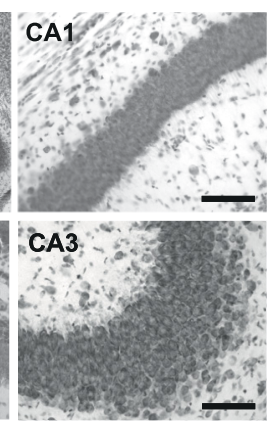

wt

GluN2B ${ }^{\triangle G A D 67}$

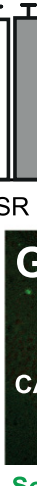

Somatostatin

Caspase-3

Figure 4. Hippocampal architecture and distribution of INs. $\boldsymbol{A}$, Nissl staining of a coronal section of the hippocampal formation in GluN2B ${ }^{\triangle G A D 67}$ and littermate wt mice at P12. Scale bars: overview, $400 \mu \mathrm{m} ;$ CA1, CA3, DG, $70 \mu \mathrm{m}$. $\boldsymbol{B}$, Expression of GAD67 mRNA in a coronal section of the dorsal hippocampus in GluN2B ${ }^{\triangle G A D 67}$ and littermate wt mice at P12. Scale bar, $400 \mu \mathrm{m}$. C, Quantification of GAD67 mRNA-expressing cells per section in the stratum oriens (SO), stratum radiatum (SR), hilus and granule cell layer $(\mathrm{GCL})$ of the $D G$ in GluN2B ${ }^{\triangle \mathrm{GAD} 67}$ and littermate wt mice (all n.s., $t$ test, respectively, $n=4$ mice per genotype). $\mathrm{PV}^{+}(\boldsymbol{D})$ and somatostatin ${ }^{+}(\boldsymbol{E})$ cells in the hippocampus expressed (re in GAD67:Cre + mice at P12. Scale bar, $20 \mu \mathrm{m}$. Expression of activated caspase-3 and PV ${ }^{+}(\boldsymbol{F})$ or somatostatin ${ }^{+}(\boldsymbol{G})$ cells in the hippocampus of GluN2B ${ }^{\Delta \mathrm{GAD} 67}$ mice at P15. Scale bar, $100 \mu \mathrm{m}$. CC, corpus callosum.

( $p<0.001$, Mann-Whitney test; Fig. 5B,E) compatible with the ablation of the dominant GluN2 subunit in postnatal development. Interestingly, the ratio of AMPAR-mediated eEPSCs over gabazinesensitive eIPSCs was increased in GluN2B ${ }^{\Delta \mathrm{GAD} 67}$ mice compared with control littermates $(p<0.001$, Mann-Whitney test; Fig. $5 C, F)$. The paired-pulse ratio of AMPAR-mediated eEPSCs was similar in GluN2B ${ }^{\Delta \mathrm{GAD} 67}$ and control neurons (n.s., Mann-Whitney test; Fig. $5 D, G$ ), supporting that the observed amplitude changes reflect postsynaptic alterations.

We further examined potential differences in the density of active glutamatergic synapses and measured sEPSCs in the absence of inhibitory transmission (gabazine $10 \mu \mathrm{M}$; Fig. $6 A$ ). Here, in GluN2B ${ }^{\Delta \mathrm{GAD} 67}$ mice the frequency of sEPSCs was decreased whereas the amplitude of sEPSCs was increased compared with age-matched wild-type controls (Fig. 6B, C). In stratum oriens, these changes were consistently observed in fastspiking (Fig. 6B) and nonfast-spiking INs (Fig. 6C). We also accounted for possible effects of knock-in of the Cre gene into the gad 1 locus. However, we observed no difference between GAD67:Cre+ and GAD67:Cre - mice of control mice carrying wild-type alleles of GluN2B (GluN2B wt/wt; Fig. 6B, C). To exclude influences of the network drive in the two genotypes, we repeated the experiment and measured action potential-independent mEPSCs in the presence of the sodium channel blocker tetrodotoxin $(1 \mu \mathrm{M})$. Again,

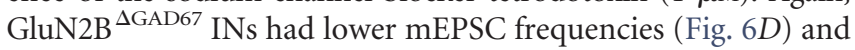

larger amplitudes of mEPSCs (Fig. 6E) compared with INs in littermate control mice ( $n=11$ cells, respectively, in four mice per genotype). Again, control mice (GluN2B $^{\mathrm{wt} / \mathrm{wt}}$ ) displayed similar mEPSC amplitudes and frequencies independent of whether they were GAD67:Cre+ and GAD67:Cre- (Fig. 6D,E). We finally tested whether the reduced number of functional glutamatergic inputs to $\mathrm{PV}^{+}$INs in stratum oriens might result in a decrease in the number of presynaptic release sites. As a proxy, we examined in confocal sections the density of VGlut ${ }^{+}$puncta at $\mathrm{PV}^{+}$proximal dendrites at P12. We found no significant difference in the densities of VGlut ${ }^{+}$ puncta in GAD67:Cre + and GAD67:Crecontrol (GluN2B ${ }^{\text {wt/wt }}$ ) and GluN2B ${ }^{\Delta \text { GAD67 }}$ mice $(1.08 \pm 0.09,1.02 \pm 0.06$, and $0.89 \pm$ $0.11 \mathrm{puncta} / \mu \mathrm{m}$ dendrite, 24 cells in three mice for each genotype, respectively; n.s., ANOVA). Together, these observations demonstrate that deletion of GluN2B reduced the density of functional AMPARmediated glutamatergic synapses of INs.

\section{Discussion}

\section{Deletion of GluN2B in INs does not} interfere with cortical circuit assembly In this study, we examined the function of GluN2B in postnatal IN development by conditional ablation of the receptor subunit in GAD67-expressing neurons. GluN2B ${ }^{\Delta \mathrm{GAD} 67}$ mice exhibited a phenotype quite distinct from that reported for mice with global GluN2B deletion. Deletion of GluN2B in INs resulted in status epilepticus and death of the animals after the second postnatal week. In contrast, mice with global deletion of GluN2B in pyramidal neurons die already after birth as a consequence of an impaired suckling response (Kutsuwada et al., 1996).

At the gross anatomical level, there was no conspicuous alteration in the somatosensory barrel structure of GluN2B ${ }^{\Delta \mathrm{GAD} 67}$ mice. This is in stark contrast with the reported abnormality of the barrel structure in mice with global deletion of GluN2B (Kutsuwada et al., 1996). As previously shown AMPARs, but not NMDARs, are critical for migration of forebrain INs (Manent et al., 2006). In support of this study, the number and distribution of GAD67-expressing INs was normal in the hippocampus of GluN2B ${ }^{\Delta \text { GAD67 }}$ mice, indicating that deletion of the GluN2B subunit did not interfere with the migration of these INs in our mutant mice. Together conditional GluN2B deletion in IN did not detectably impair the structural assembly of cortical circuits or the distribution of INs within these circuits.

\section{Deletion of GluN2B reduces the density of glutamatergic synapses in INs}

As the number and distribution of GAD67-expressing INs was not altered by GluN2B deletion, we focused on the role of GluN2B in the synaptic development of INs during the first postnatal weeks. At this developmental stage (starting at P10), no synaptic NMDAR responses were detectable in stratum 


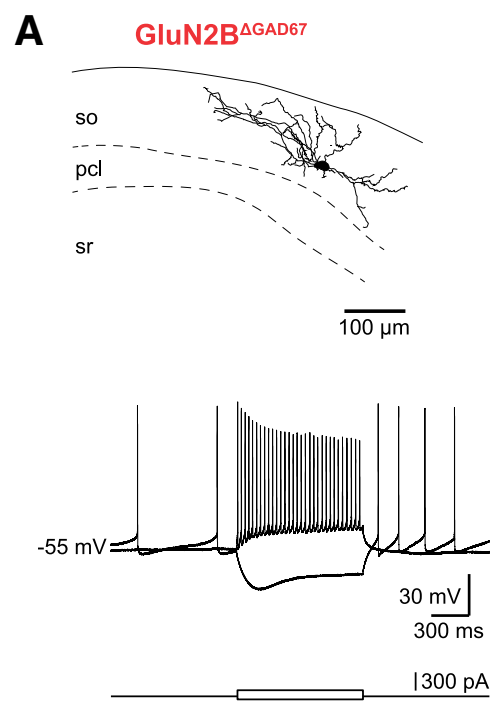

B
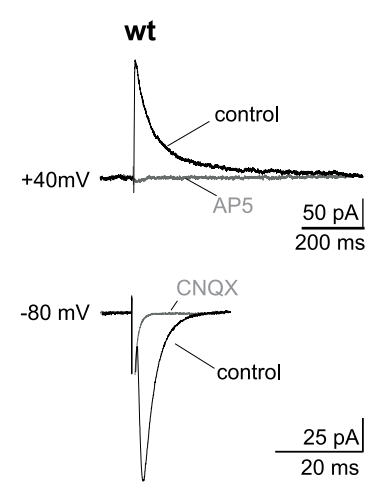
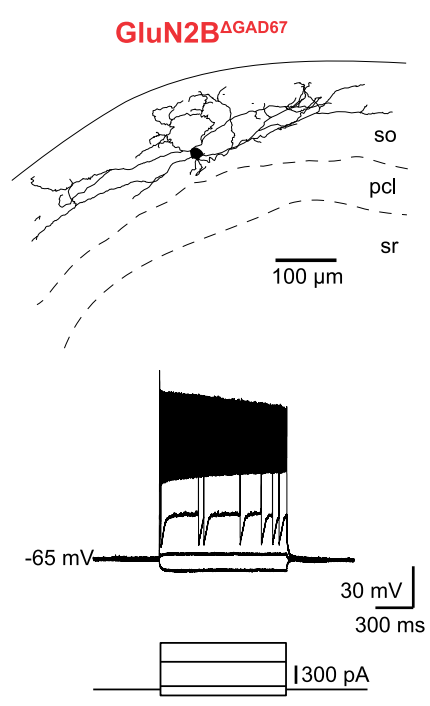

D
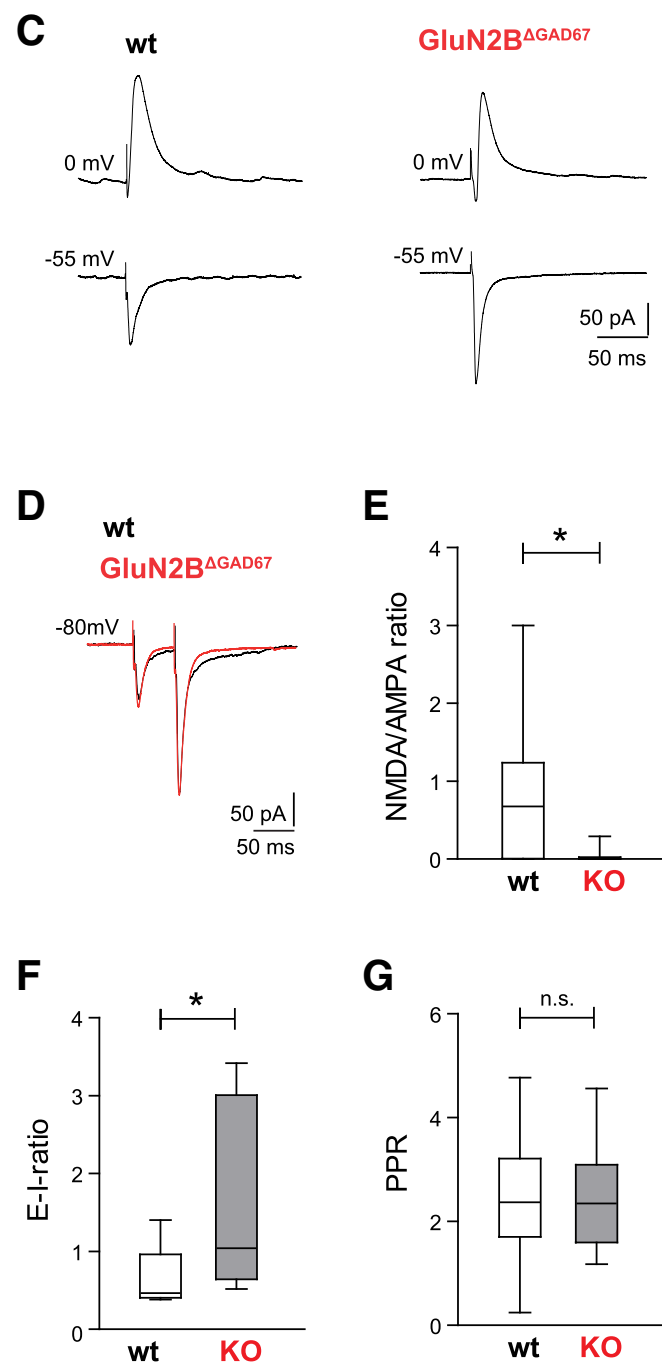

E

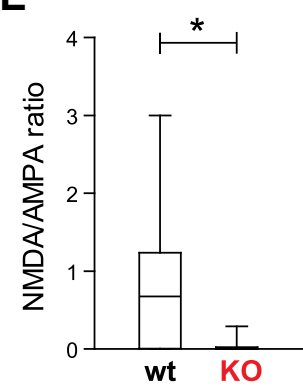

G
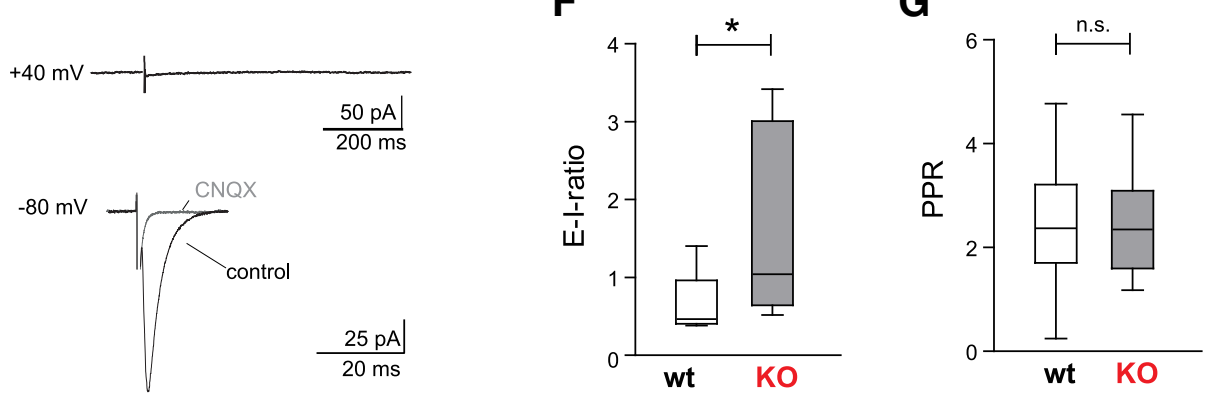

Figure 5. Development of glutamatergic inputs to INs in GluN2B ${ }^{\triangle \mathrm{GAD} 67}$ mice. $A$, Reconstructions of the dendrites of two biocytin-filled GluN2B ${ }^{\triangle \mathrm{GAD} 67}$ mouse INs with the cell body in the stratum oriens (so). Scale bar, $100 \mu \mathrm{m}$. Below the corresponding firing pattern upon current injection (1 s) of the two INs shown above (no current was injected between current steps, $V_{\mathrm{m}}=-55$ and $-65 \mathrm{mV}$, respectively). $\boldsymbol{B}$, Representative average traces of CNQX $(10 \mu \mathrm{M})$-sensitive AMPAR-mediated eEPSCs $\left(V_{\mathrm{h}}=-80 \mathrm{mV}\right.$, in the presence of $10 \mu \mathrm{m}$ gabazine) in $w t$ and GluN2B ${ }^{\triangle G A D 67}$ INs. D-AP5 $(50 \mu \mathrm{m})$-sensitive NMDAR-mediated eEPSCs were detected in wt, but not GluN2B ${ }^{\triangle G^{\prime} A D 67}$ INs $\left(V_{\mathrm{h}}=+40 \mathrm{mV}\right.$, in the presence of $10 \mu \mathrm{m}$ gabazine and $10 \mu \mathrm{m}$ CNQX). C, Averaged traces from elPSCS $\left(V_{h}=0 \mathrm{mV}\right)$ and EPSCS $\left(V_{\mathrm{h}}=-55 \mathrm{mV}\right.$, in the presence of $10 \mu \mathrm{m}$ gabazine) in wt and GluN2B ${ }^{\Delta G A D 67}$ INs. All recordings were performed in the presence of D-AP5 $(50 \mu \mathrm{M})$. $\boldsymbol{D}$, Representative average traces of facilitating AMPAR-mediated eEPSCs in response to paired pulses $\left(V_{\mathrm{h}}=-80 \mathrm{mV}\right.$, in the presence of $\left.10 \mu \mathrm{m} \mathrm{gabazine}\right)$ in wt and GluN2B ${ }^{\Delta G A D 67}$ INs. $\boldsymbol{E}$, Ratio of NMDAR/AMPAR-mediated eEPSCs in GluN2B ${ }^{\Delta G A D 67}$ mice (13 cells) compared with age-matched wt littermates (15 cells; Mann-Whitney test). $\boldsymbol{F}$, The ratio of AMPAR-mediated eEPSCs over gabazine-sensitive elPSCs in GluN2B ${ }^{\triangle G A D 67}$ mice (8 cells) compared with control littermates ( 9 cells; Mann-Whitney test). G, Paired-pulse ratio of AMPAR-mediated eEPSCs in GluN2B ${ }^{\triangle G A D 67}$ and control neurons (22 and 25 cells, respectively, Mann-Whitney test. All data shown as box-plot with mean whiskers (5-95th percentile). Pcl, pyramidal cell layer; sr, stratum radiatum.

oriens INs of GluN2B ${ }^{\Delta \mathrm{GAD} 67}$ mice as expected after removal of the dominant GluN2 subunit during development. During the second to third postnatal week, GluN2B-containing NMDARs have a negative regulatory effect on the maturation of AMPAR-mediated glutamatergic synapses in hippocampal pyramidal cells as revealed by increased mEPSC frequencies upon GluN2B deletion (Hall et al., 2007; Gray et al., 2011; Wang et al., 2011). Based on these observations an activitydependent scenario was proposed according to which GluN2B-containing NMDARs set a brake on the maturation of glutamatergic synapses at a time when synaptic activity has not fully developed yet in the hippocampus (Hall et al., 2007; Adesnik et al., 2008; Gray et al., 2011). In our study, we demonstrate that at the same postnatal stage GluN2B-containing NMDARs have an opposing effect on synapse maturation in hippocampal INs since deletion of GluN2B resulted in de- creased mEPSC frequencies. GluN2B-containing receptors promote maturation of glutamatergic input to INs and thereby recruitment of inhibitory neurons by the excitatory drive.

In hippocampal pyramidal neurons, deletion of GluN2B increases the frequency of EPSCs, but not their amplitude, whereas GluN2A deletion affects the amplitude but not frequency of EPSCs (Hall et al., 2007; Gray et al., 2011; Wang et al., 2011). In interneurons of the same circuit, GluN2B deletion resulted in a decrease of EPSC frequency and an increase in EPSC amplitude. The site of EPSC amplitude changes was most likely postsynaptic since the paired-pulse ratio did not differ between GluN2B ${ }^{\triangle \mathrm{GAD} 67}$ and control INs. It is possible that the scaling of AMPAR-mediated EPSC amplitudes is a compensatory effect (Wierenga et al., 2005) for the reduced excitatory drive to INs by the lower density of functional glutamatergic synapses or the 
A

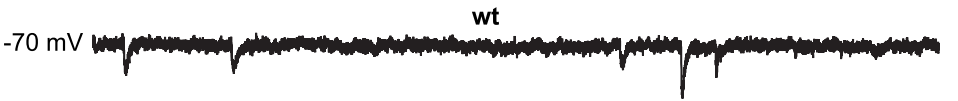

GluN2B $^{\Delta G A D 67}$

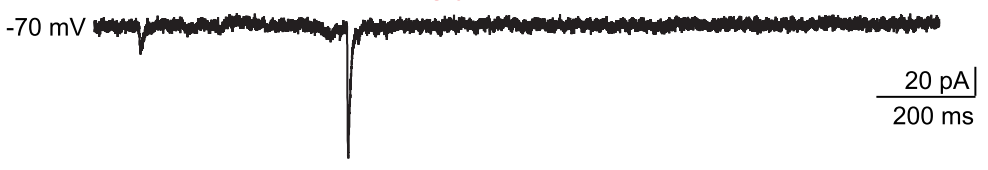

B str. oriens: fast-sipiking neurons
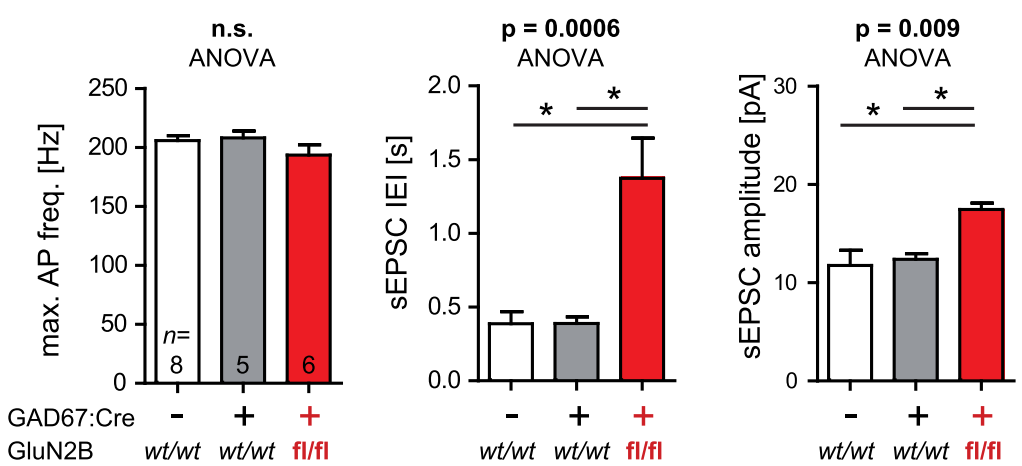

C str. oriens: non-fast-sipiking neurons
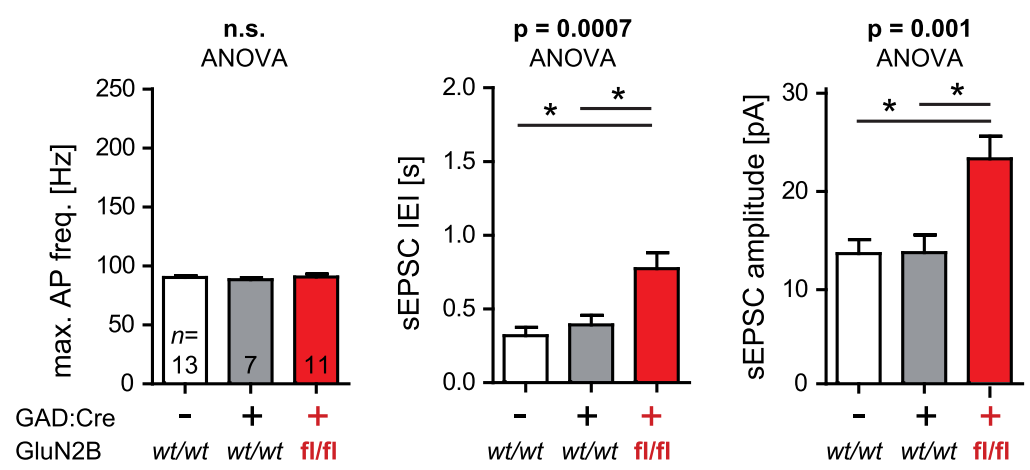

D

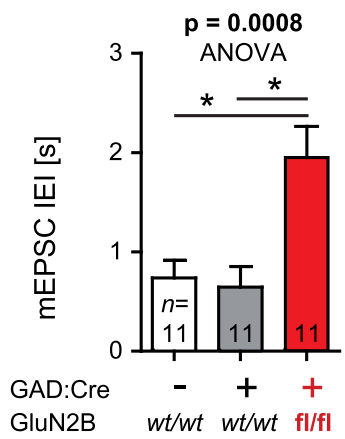

E

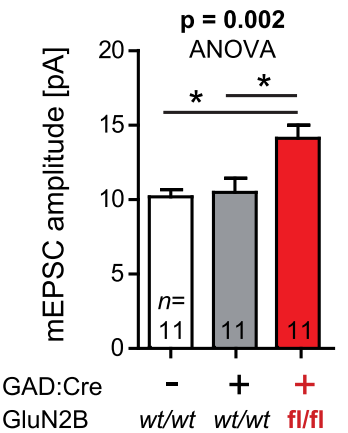

Figure 6. Development of glutamatergic synapses in GluN2B ${ }^{\triangle \mathrm{GAD} 67}$ mice. $\boldsymbol{A}$, Recordings of sEPSCs $\left(V_{\mathrm{h}}=-70 \mathrm{mV}\right.$, in the presence of $10 \mu \mathrm{m}$ gabazine) in stratum oriens neurons of GluN2B ${ }^{\Delta G_{A D} 67}$ and littermate wt mice at P12. Stratum oriens neurons were sorted into fast-spiking $(\boldsymbol{B})$ and nonfast-spiking $(\boldsymbol{C})$ neurons according to their maximum firing rate upon current injection (left graphs). The mean interevent intervals (IEl; middle graphs) and amplitudes of sEPSCs (right graphs) in stratum oriens neurons of GluN2B ${ }^{\triangle \mathrm{GAD} 67}$ and age-matched littermate wt (GAD67:Cre + and GAD67:(re - /GluN2B ${ }^{\text {wt/wt }}$ ) mice, respectively. Mean IEIs $(\boldsymbol{D})$ and amplitudes $(\boldsymbol{E})$ of $\mathrm{mEPSC}$ in all recorded stratum oriens neurons of GluN2B ${ }^{\triangle G A D 67}$ and age-matched littermate wt (GAD67:Cre + and GAD67:Cre - /GluN2B wt/wt) mice (all three genotypes: $n=11$, respectively; $V_{\mathrm{h}}=-70 \mathrm{mV}$, in the presence of $10 \mu \mathrm{m}$ gabazine and $1 \mu \mathrm{m}$ tetrodotoxin). In $\boldsymbol{B}-\boldsymbol{E}$ an ANOVA with post-test $\left({ }^{*} p<0.05\right)$ was applied. beginning seizure discharges in the hippocampus. The question of whether the amplitude scaling is directly mediated by GluN2B deletion or develops in response to epileptic discharges may require future studies using GluN2B deletion in single INs to control for potential compensatory effects due to altered circuit activity.

The reduction in EPSC frequency in GluN2B-deficient INs is unlikely to reflect compensation since the reduced drive of inhibitory neurons will further increase excitation in the circuit. Finally, the same changes in synapse development were also observed in adult-born INs in which sparse retroviral single-cell knock-out of GluN2B largely precluded system effects (Kelsch et al., 2012). Together these observations suggest that at least in two IN types GluN2B-containing NMDARs have a promaturational effect on glutamatergic synapses. The promotion of the functional development of glutamatergic inputs to INs may act synergistically with the negative regulation of synapse maturation observed in neighboring excitatory neurons in the developing circuit. While the excitatory drive drastically increases during the first postnatal weeks, negative regulation of glutamatergic input to excitatory neurons as well as increased recruitment of interneurons by activitydependent maturation of excitatory synapses onto these INs may keep the circuit under control. In line with these observations, ablation of GluN2B in INs results in fatal seizures as the synaptic activity gradually increases.

\section{Deletion of GluN2B in INs results in} fatal neonatal seizures

GluN2B ${ }^{\Delta \text { GAD67 }}$ animals died of seizures between P15 and P20, the age corresponding to the peak of hippocampal and cortical synaptogenesis (Vaughn, 1989). The decreased excitation of INs is not sufficiently compensated by the amplitude scaling of EPSCs onto INs to prevent seizures. INs and genetic alterations in NMDAR subunits have been implicated in the pathogenesis of neurodevelopmental disorders (Homayoun and Moghaddam, 2007; Pinto et al., 2010; Gai et al., 2012). Within the spectrum of neurodevelopmental disorders, seizures are a frequent symptom in postnatal development. Depending on the extent of GluN2B-containing NMDAR malfunction and subsequent excitation/inhibition imbalance, the behavioral consequences may range from cognitive impairment to severe seizures. 


\section{References}

Adesnik H, Li G, During MJ, Pleasure SJ, Nicoll RA (2008) NMDA receptors inhibit synapse unsilencing during brain development. Proc Natl Acad Sci U S A 105:5597-5602. CrossRef Medline

Carter RJ, Lione LA, Humby T, Mangiarini L, Mahal A, Bates GP, Dunnett SB, Morton AJ (1999) Characterization of progressive motor deficits in mice transgenic for the human Huntington's disease mutation. J Neurosci 19:3248-3257. Medline

Catania MV, Tölle TR, Monyer H (1995) Differential expression of AMPA receptor subunits in NOS-positive neurons of cortex, striatum, and hippocampus. J Neurosci 15:7046-7061. Medline

Chattopadhyaya B, Di Cristo G, Wu CZ, Knott G, Kuhlman S, Fu Y, Palmiter RD, Huang ZJ (2007) GAD67-mediated GABA synthesis and signaling regulate inhibitory synaptic innervation in the visual cortex. Neuron 54: 889-903. CrossRef Medline

Erlander MG, Tillakaratne NJ, Feldblum S, Patel N, Tobin AJ (1991) Two genes encode distinct glutamate decarboxylases. Neuron 7:91-100. CrossRef Medline

Forrest D, Yuzaki M, Soares HD, Ng L, Luk DC, Sheng M, Stewart CL, Morgan JI, Connor JA, Curran T (1994) Targeted disruption of NMDA receptor 1 gene abolishes NMDA response and results in neonatal death. Neuron 13:325-338. CrossRef Medline

Gai X, Xie HM, Perin JC, Takahashi N, Murphy K, Wenocur AS, D’arcy M, O'Hara RJ, Goldmuntz E, Grice DE, Shaikh TH, Hakonarson H, Buxbaum JD, Elia J, White PS (2012) Rare structural variation of synapse and neurotransmission genes in autism. Mol Psychiatry 17:402-411. CrossRef Medline

Gray JA, Shi Y, Usui H, During MJ, Sakimura K, Nicoll RA (2011) Distinct modes of AMPA receptor suppression at developing synapses by GluN2A and GluN2B: single-cell NMDA receptor subunit deletion in vivo. Neuron 71:1085-1101. CrossRef Medline

Hall BJ, Ripley B, Ghosh A (2007) NR2B signaling regulates the development of synaptic AMPA receptor current. J Neurosci 27:13446-13456. CrossRef Medline

Homayoun H, Moghaddam B (2007) NMDA receptor hypofunction produces opposite effects on prefrontal cortex interneurons and pyramidal neurons. J Neurosci 27:11496-11500. CrossRef Medline

Iwasato T, Datwani A, Wolf AM, Nishiyama H, Taguchi Y, Tonegawa S, Knöpfel T, Erzurumlu RS, Itohara S (2000) Cortex-restricted disruption of NMDAR1 impairs neuronal patterns in the barrel cortex. Nature 406: 726-731. CrossRef Medline

Kelsch W, Li Z, Eliava M, Goengrich C, Monyer H (2012) GluN2Bcontaining NMDA receptors promote wiring of adult-born neurons into olfactory bulb circuits. J Neurosci 32:12603-12611. CrossRef Medline

Kutsuwada T, Sakimura K, Manabe T, Takayama C, Katakura N, Kushiya E, Natsume R, Watanabe M, Inoue Y, Yagi T, Aizawa S, Arakawa M, Takahashi T, Nakamura Y, Mori H, Mishina M (1996) Impairment of suckling response, trigeminal neuronal pattern formation, and hippocampal LTD in NMDA receptor epsilon 2 subunit mutant mice. Neuron 16:333344. CrossRef Medline

Li Y, Erzurumlu RS, Chen C, Jhaveri S, Tonegawa S (1994) Whisker-related neuronal patterns fail to develop in the trigeminal brainstem nuclei of NMDAR1 knockout mice. Cell 76:427-437. CrossRef Medline

Magno L, Kretz O, Bert B, Ersözlü S, Vogt J, Fink H, Kimura S, Vogt A, Monyer H, Nitsch R, Naumann T (2011) The integrity of cholinergic basal forebrain neurons depends on expression of Nkx2-1. Eur J Neurosci 34:1767-1782. CrossRef Medline

Manent JB, Jorquera I, Ben-Ari Y, Aniksztejn L, Represa A (2006) Glutamate acting on AMPA but not NMDA receptors modulates the migration of hippocampal interneurons. J Neurosci 26:5901-5909. CrossRef Medline

Monyer H, Burnashev N, Laurie DJ, Sakmann B, Seeburg PH (1994) Developmental and regional expression in the rat brain and functional properties of four NMDA receptors. Neuron 12:529-540. CrossRef Medline

Nakanishi S (1992) Molecular diversity of glutamate receptors and implications for brain-function. Science 258:597-603. CrossRef Medline

Pinto D, Pagnamenta AT, Klei L, Anney R, Merico D, Regan R, Conroy J, Magalhaes TR, Correia C, Abrahams BS, Almeida J, Bacchelli E, Bader GD, Bailey AJ, Baird G, Battaglia A, Berney T, Bolshakova N, Bölte S, Bolton PF, et al. (2010) Functional impact of global rare copy number variation in autism spectrum disorders. Nature 466:368-372. CrossRef Medline

Platel JC, Kelsch W (2013) Role of NMDA receptors in adult neurogenesis: an ontogenetic (re)view on activity-dependent development. Cell Mol Life Sci 70:3591-3601. CrossRef Medline

Rostock A, Tober C, Rundfeldt C, Bartsch R, Engel J, Polymeropoulos EE, Kutscher B, Löscher W, Hönack D, White HS, Wolf HH (1996) D-23129: a new anticonvulsant with a broad spectrum activity in animal models of epileptic seizures. Epilepsy Res 23:211-223. CrossRef Medline

Tamamaki N, Yanagawa Y, Tomioka R, Miyazaki J, Obata K, Kaneko T (2003) Green fluorescent protein expression and colocalization with calretinin, parvalbumin, and somatostatin in the GAD67-GFP knock-in mouse. J Comp Neurol 467:60-79. CrossRef Medline

Tashiro A, Sandler VM, Toni N, Zhao C, Gage FH (2006) NMDA-receptormediated, cell-specific integration of new neurons in adult dentate gyrus. Nature 442:929-933. CrossRef Medline

Tolu S, Avale ME, Nakatani H, Pons S, Parnaudeau S, Tronche F, Vogt A, Monyer H, Vogel R, de Chaumont F, Olivo-Marin JC, Changeux JP, Maskos U (2010) A versatile system for the neuronal subtype specific expression of lentiviral vectors. FASEB J 24:723-730. CrossRef Medline

Vaughn JE (1989) Fine-structure of synaptogenesis in the vertebrate central nervous-system. Synapse 3:255-285. CrossRef Medline

von Engelhardt J, Doganci B, Jensen V, Hvalby Ø, Göngrich C, Taylor A, Barkus C, Sanderson DJ, Rawlins JNP, Seeburg PH, Bannerman DM, Monyer H (2008) Contribution of hippocampal and extra-hippocampal NR2Bcontaining NMDA receptors to performance on spatial learning tasks. Neuron 60:846-860. CrossRef Medline

Wang CC, Held RG, Chang SC, Yang L, Delpire E, Ghosh A, Hall BJ (2011) A critical role for GluN2B-containing NMDA receptors in cortical development and function. Neuron 72:789-805. CrossRef Medline

Wierenga CJ, Ibata K, Turrigiano GG (2005) Postsynaptic expression of homeostatic plasticity at neocortical synapses. J Neurosci 25:2895-2905. CrossRef Medline 